\title{
In Search of One's Past: An Identity Trip.
}

\author{
FERNANDO COLÓN, PH.D. ${ }^{a}$ \\ ${ }^{a}$ Counselling Center and Department of Psychology, University of Michigan, Ann Arbor, Michigan.
}

The experience of being "cut off," either emotionally or physically, from one's family of origin and extended families is an experience that at times confronts us all, be we the children of natural, adoptive, foster or divorced parents. The goal of this paper is to show that a person's identity is profoundly related to, and affected by, his sense of connection to his family of origin. This paper will take as its point of departure the author's story as a foster child and will describe his successful effort to get himself reconnected to his natural family. The story raises questions about the policies of foster-care agencies and, by implication, questions about adoptive agency policy. Finally, the paper may have something to say not only to family therapists and researchers but to all of us who wish to more fully "know" our parents and our extended families.

\section{THE CHILDHOOD YEARS: 0-17 YEARS}

I was born in New York City in September of 1935. Six weeks after my birth I was placed with a foster-care agency because my parents were unable to care for me. By the time I was two years old I was placed in my third foster home. I remember that move and how confusing and upsetting it was. I remember wondering who these new people were and where my real parents were. I remember not talking for several weeks until I felt safe enough to do so. I remained there for the next fifteen years, until I graduated from high school. During those fifteen years I was repeatedly told that upon graduating from high school I would be on my own. During that time I had a series of ten foster brother-some older than I and others younger — who came and went. They stayed varying lengths of time, ranging from one month to four years. Each time one of them came or went it was upsetting to me. I worried about whether I, too, would someday have to leave. After a foster brother left it hit me very hard, and it took me a long time to figure out that my repeated experiences of depressions were in fact mourning reactions.

From the time of my birth until I was sixteen years old, my father visited me aperiodically and corresponded with me. This, too, was an upsetting experience, because it made me feel conflicted about my loyalties to my foster parents and to my father. In retrospect, though, I'm grateful that my father did maintain the contact because it kept alive my connection to my natural family. Until I was seven I had no idea of what had happened to my mother. Then my father told me she had died shortly after my birth; it made me feel very sad because then I realized that I would never see my real mother.

During these childhood years there were two visits from relatives from my family of origin: one with my father's sister and one with my mother's uncle and her nephew, my first cousin. I was between seven and eight years old at the time, and it was not at all clear who these people were or how they were related to me.

In 1951, when I was 16 years old, my father left the Army and returned home to Puerto Rico. The idea was that I would stay in foster home number three until I graduated from high school. Then I would go on to college in the United States and hopefully live "the good life." Before my father left, we talked about the possibility of visiting him one day in Puerto Rico.

\section{THE EARLY ADULT YEARS: 17-33 YEARS}

I sought further answers to my questions about my mother when I was 17 years old and about to leave for college. The prospect of "being on my own" must have frightened me and made me fear being cut off and alone. Although I had made a good adjustment at foster home number three, it was crystal clear that upon graduating from high school there would be no more continued emotional and physical support. It had the effect of causing my need to know more about my natural family to surface again. I wrote a series of letters to both my father and the foster-care agency asking them questions. Their respective replies now form a collection of letters, but by the time I was ready to go to college my total knowledge of my family was very meager, indeed. It consisted of the following facts related to me by my father: that my parents were from Puerto Rico, that they had met and married in New York City in the early 1930's, that after my birth in 1935 I was placed with a foster-care agency because my mother died shortly after childbirth and my father felt unable to care for me.

From the time I was seventeen years old in 1952 until my first visit to Puerto Rico in 1968 when I was thirty-three, my father and I did not correspond frequently. Nevertheless, we did manage to maintain a thin thread of connection to each other, and during those years I slowly accumulated additional bits and pieces of information about my families of origin. When I was eighteen, I learned my mother's name. When I was nineteen and a sophomore in college I learned that both of my parents' parents were farmers, that my paternal grandmother was still alive, and that my maternal grandparents had died when my mother was a child. Learning these facts made me feel better. It was comforting to know that I, too, had a real 
family and I didn't feel so alone, but the connections still did not feel all that real.

At the end of my junior year in college I got married. Two years later I was a second-year graduate student in clinical psychology. During that year, in response to the birth announcement of our first child and further questions on my part, my father shared more facts with me about my extended families. It turned out that he was one of ten siblings, having four brothers and five sisters. He again stated he didn't know much about my mother's family except that she had a sister who had three children, one of whom visited me with my mother's uncle when I was seven or eight years old.

In 1960, when I was twenty-five years old and a fourth-year graduate student, I wrote to my father and told him that we were expecting our second child. I also asked him if he would recount my early childhood history, since it had always been fuzzy and unclear to me. He responded with a very moving letter that yielded some new facts about my mother. After my birth she became ill and was returned to Puerto Rico to try to regain her health. My father remained in the United States in the Army. My mother failed to recover and died in 1936. It is important to note that the new data typically came in response to the birth announcements of our children or the reporting of other key family events, and in conjunction with my further questions.

In March of 1967 I attended a conference at the Eastern Pennsylvania Psychiatric Institute on "Systematic Research and Family Interaction." At this meeting I heard Murray Bowen present his twelve years' effort at working with his family. I was stimulated by his presentation and thought that this man had to be on the right track. Although he described his effort with his intact family system and his family situation was quite different from mine, his story gave me much food for thought. It was obvious that he had developed an advanced view about the family as a system. I was eager to learn more about his ideas and arranged to observe him work for the next year or so and slowly acquired a cognitive map of his systems view of the family. I liked the way he actively maintained contact with the members of his family. It gave me added support for the thrust of my movement toward my family.

By the time I was thirty-three years old, I had a collection of letters from both my father and the foster-care agency that were written during the preceding sixteen-year period. As I put the pieces of information about my family together from these letters, it became clear that some of my father's letters contained inconsistencies and that the agency was telling a different story from that of my father and that neither of them was telling the full story despite my numerous attempts to get the full story. Consequently, I decided that the time had come for me to visit Puerto Rico in order to re-establish face-to-face contact with my father and to see if I could learn "first-hand" more about my extended families.

\section{THE ACTIVE SEEKING YEARS: 33-37 YEARS}

I made my first visit to Puerto Rico with my wife and children to visit my father in July of 1968. I was thirty-three years old and it had been seventeen years since I last saw my father when he left New York in 1951. I felt both anxious and excited. I wasn't sure how we would get along after such a long separation. But it turned out very well, so that seeing him, meeting all of my paternal aunts and uncles and cousins was a staggering but joyful experience. We spent two weeks meeting all the people of my father's extended family. On one of the visits to a paternal uncle's home, my father mentioned in passing the name of my mother's home town. When I inquired about my mother's family, my father reported that he had had no contact with them and that none of her family was now living in Puerto Rico. He said that all of them went to the United States years ago and that maybe some of them were in Washington, D.C., but he didn't know for certain.

Midway through this first Puerto Rico trip, while visiting one of my uncles, his wife suddenly brought out an old paper sack. She asked my father if she could show its contents to me. He consented.It contained my parents wedding picture. It was the first time I had ever seen a picture of my mother! It was a stunning experience! What was compelling about the photograph was the striking physical resemblance of my mother's face to my own. My uncle let me take the picture with the understanding that I would have it copied and return it. Seeing my mother's picture stimulated still more unanswered questions about her and her family. I again wondered what she was like, what had really happened to her, what her family was like, and would I some day be able to find them.

At the end of July, 1968, my family and I returned home. I left feeling really tremendous after having the experience of seeing my father and meeting his part of my family. I felt reconnected to him and in touch again. It gave me a solid sense of my identity — as though I really had one of my feet under me now. There remained unanswered questions about the other half of my identity. It was clear that my father did not want to get into questions about my mother. I arrived home with the sense of a still incomplete story, and I thought that my father was still withholding some very vital information.

Then in June of 1969 I attended a thirty-member Family Therapy Workshop conducted by Virginia Satir. During the course of the week she mentioned the family reconstruction technique. I was intrigued and volunteered to be the subject because I saw it as a way of focusing on some of my unanswered questions about my mother. The technique consisted of my selecting members from the group (whom by now I had gotten to know and trust) to represent all of the significant 
others of my life from the time of my birth until I left home for college. After these persons were selected and defined, I was asked to talk to them about unresolved issues from the past that involved each of them and me. It turned out to be a tremendously important experience because it enabled me to psychologically "recover" my mother, my foster father, and my foster brothers, all of whom I had previously lost through deaths or permanent separations. The experience taught me an immensely profound lesson: namely, that physical separations or death need not be experienced as permanently irretrievable losses. One's memories of those lost others can keep them very much alive and they, therefore, remain a significant part of one, which indeed they are. This was a very moving and profoundly "integrative" experience. It enabled me to reconnect to the whole sequence of significant others who had entered and left my life during my childhood years. It was a peak experience and left me feeling psychologically high for a number of days after the actual experience itself.

Although the experience did not answer any of my questions about my mother, it did suggest new hypotheses and raise new questions that I hadn't thought of before. It also meant that my father was about to receive another one of my letters which by now he was probably beginning to dread. Immediately after the workshop, I wrote again to my father and suggested that on my next visit to Puerto Rico we both visit my mother's hometown to search for her family. There was no response to this letter nor any mention of this proposal thereafter. My father's lack of response told me that I was on the right track and that one day I would have to return to search for my mother's family by myself.

By the end of the summer of 1971, after an additional round of letters between me and my father and the foster-care agency, I was still convinced that I had not yet been told the full story. I decided to return to Puerto Rico to focus on finding my mother's family. I decided to go alone so I wouldn't have the added complication of worrying about my wife and children at the same time. I prepared for the trip by studying Spanish daily for about two months so that I would have at least a rudimentary listening and speaking knowledge of the language.

My first few days after I arrived in Puerto Rico I visited with my father. He gave me two more pictures of my mother and told me that she was a Baptist. Although he had previously told me the name of my mother's hometown, he now said he didn't know how to get there. I took this to mean that for him it was psychologically true that he did not know the way back to her family, when in actuality, of course, he did know the way back to the town. I had thought of getting my paternal aunt's husband to go with me to search, because he speaks both English and Spanish, but decided against it because I feared that it would create divisiveness within my father's family.

So I went alone, borrowing my dad's car, but "failed" to tell him exactly where I was going. I picked up a road map and found my way to my mother's home town. Within an hour of my arrival, I succeeded in finding my mother's extended family! I did this with the aid of the local Baptist minister. It turned out that my mother's sister, my maternal aunt, lived right across the street from the church! Upon meeting me, my aunt burst into tears of wonderment and joy and exclaimed, "La cara! La cara!" The face! The face! because my face bears such a striking resemblance to my mother's face. At first I still was not convinced that she was my aunt. So she ran back into the house and brought out snapshots of me given to her by her uncle after he visited me with her son, my cousin, in New York when I was about seven or eight years old. So the link-up was validated, and again I was stunned with joy. My aunt then wanted me to stay for supper and meet the rest of my family. I happily agreed, but called my father to tell him where I was and that I would be getting home late that night. I knew that he immediately realized what I had probably done, but he didn't ask and I didn't tell him about it, because I preferred a face-to-face discussion with him.

I then met the other members of my mother's extended family. I learned that after my birth, when my mother became ill, she did, indeed, return to Puerto Rico to live on her uncle's farm. However, she did not get better and was subsequently placed in a psychiatric hospital where she stayed for twenty-five years until she died in 1962. Thus, she did not die in 1936. During the next two days I made two visits to the psychiatric hospital where my mother received care. I obtained permission to review her voluminous record, which contained specific dates and events. Finally—at long last, I had the complete story.

At this point I was suddenly in the position of knowing more about what had happened to my mother than my father did. After my mother's return to Puerto Rico in 1936, he made a complete and permanent cut-off and never had any further contact with her or her family. So now my father and I had to face each other and deal with the truth that had been buried for so long. What surfaced immediately, as we began to talk about it, was a strong reaction on the part of my father that he felt I was investigating him as if he were a criminal. I told him that I could see that he would feel that way but that I had a right to know about what had happened to my mother. It was a painful conversation, but we stayed with it and were finally able to talk openly with each other about this loaded, emotional issue. It turned out that my father feared that if I knew about my mother's illness it would affect my sanity too. That knowledge touched me deeply, and at last it all made sense.

After this conversation, my relationship to my father underwent a very noticeable change. Before this conversation, there was always that unspoken source of tension between us. Now that the truth had been discovered and talked about, that source of tension was gone and our relationship was more open and relaxed, so that a different, more harmonious sense of connection now existed between us.

Then I paid a second visit to my mother's family. I visited my mother's grave. I met many of the members of her extended 
family. We had a family feast. The whole family spent the day recalling memories of their experiences with my mother and succeeded in this way in giving her back to me. It was an incredible experience to meet them all, to see young children who look like my children, and to meet my third cousin who is my "identical look-alike." Upon experiencing the open warmth of my mother's extended family, I felt a new, more whole sense of self and a new, more flowing sense of life. It's difficult to capture the experience in words, but it was like being plugged into the electrical current or field of the family emotional system and becoming more alive and energized as a result.

On September 1, 1971, I returned home to Michigan and I felt really fantastic. I now had the other half of my identity. I now had two feet to stand on instead of one, and it was a tremendous feeling of solidness and connectedness. I had finally succeeded in reconnecting with both of my families of origin. I was left with a sense of completeness I had not known before, and it felt great. At long last I would no longer feel "different" from other people who knew and were in contact with their families. I would be able to answer the previously painful questions about my family background without awkwardness and embarrassment and, indeed, with a sense of pride.

Currently I remain in contact with both my father's and my mother's families. I plan regular visits to both extended families in the future. I anticipiate new challenges, new problems, and new opportunities as I continue to get back into the family. But along with the new challenges and problems I also anticipate deeper and more profound sources of connection, self-identity, and satisfaction.

\section{CONCLUDING REMARKS}

Although this paper describes a foster child's effort to re-unite with, and to identify himself with, his natural family, it also raises a number of questions about the adopted child, since both the adopted and the foster child share the experience of being cut off from family. It would seem that the following questions need to be raised for both the foster and the adoptive child's situation: (a) Does the cut-off child have a "right to know" about his natural parents? (b) If the child is told about his natural parents, when, how, and how much should he be told? (c) Does the child's need to know about his roots transcend the need of his natural, adoptive, or foster parents to keep his roots a secret? (d) Should all children who are cut off from their families of origin be told about their heritage? (e) Should the child actually meet and get to know his natural parents and their extended families? (f) If the cut-off child does this, what or how would he handle his relationship to his adoptive or foster family? ( $\mathrm{g}$ ) Does the cut-off child's need to know his natural family transcend the need of the adoptive or foster parents to make the child their own?

These questions suggest that there may be within each one of us a profound desire to know his roots and to be connected to them whether we are the children of natural, adoptive, foster, or divorced parents. For most individuals this need may not become salient for a variety of reasons. Indeed, most persons reared by their natural parents often only know them as parents, not as persons. But if the need to know does become salient for a given individual, no matter who reared him, should he not have the right to know, as well as the right to reconnect himself to, his natural family, if he so desires?

I believe that in the case of those who do wish to know their familial roots and who are motivated to push for the information, and perhaps a subsequent reconnection with their family, that push should be honored and supported. It could be said that the push to know would not be as strong for the adopted child, since typically the adoptive child has had no contact with his natural family and, thus, the push is not stimulated. This may be the case, but then how does one account for the need of numerous adopted children to push for such information?

This kind of phenomenon suggests that the whole question of the child's relationship to his families of origin demands much more attention and research on the part of those of us who work with families, whether the parents are natural, adoptive, foster, or divorced. At the very least, it requires us to examine again the policies and procedures that are routinely carried out in our foster-care and adoptive agencies. I firmly believe that further research into these issues will lead to an enriched and more profound view of the person and his interdependent connection to his family and that there may be lessons for all of us who wish to know and to be known by our families.

Address reprint requests to Fernando Colón, Ph.D., Counselling Center and Department of Psychology, University of Michigan, Ann Arbor, Michigan 48104. 